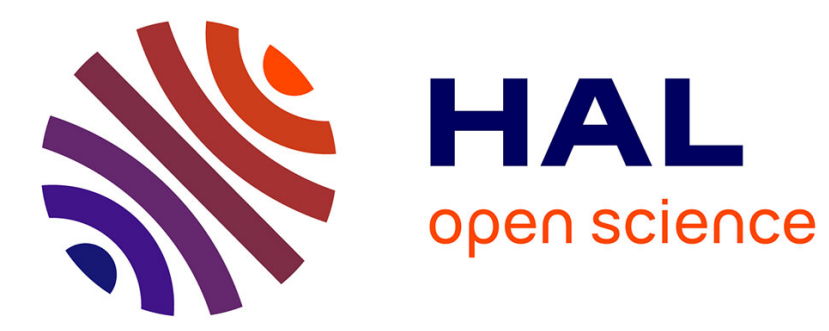

\title{
The effect of log heating temperature on the peeling process and veneer quality: beech, birch, and spruce case studies
}

Anna Dupleix, Louis Denaud, Laurent Bléron, Rémy Marchal, Mark Hughes

\section{To cite this version:}

Anna Dupleix, Louis Denaud, Laurent Bléron, Rémy Marchal, Mark Hughes. The effect of log heating temperature on the peeling process and veneer quality: beech, birch, and spruce case studies. European Journal of Wood and Wood Products, 2013, 71 (2), pp.163-171. 10.1007/s00107-012-0656-1 . hal$00844668 v 2$

\section{HAL Id: hal-00844668 \\ https://hal.science/hal-00844668v2}

Submitted on 30 Aug 2017

HAL is a multi-disciplinary open access archive for the deposit and dissemination of scientific research documents, whether they are published or not. The documents may come from teaching and research institutions in France or abroad, or from public or private research centers.
L'archive ouverte pluridisciplinaire HAL, est destinée au dépôt et à la diffusion de documents scientifiques de niveau recherche, publiés ou non, émanant des établissements d'enseignement et de recherche français ou étrangers, des laboratoires publics ou privés. 


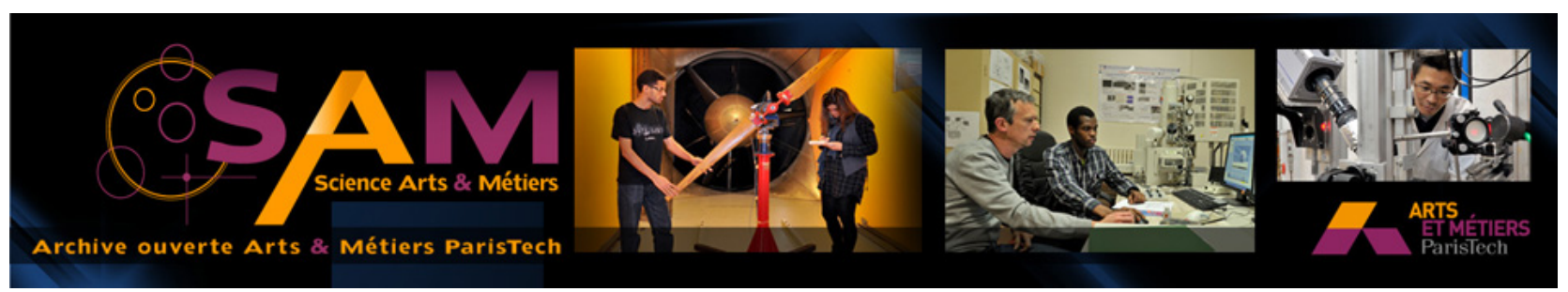

\section{Science Arts \& Métiers (SAM)}

is an open access repository that collects the work of Arts et Métiers ParisTech researchers and makes it freely available over the web where possible.

This is an author-deposited version published in: http://sam.ensam.eu

Handle ID: .http://hdl.handle.net/10985/7218

\section{To cite this version :}

Anna DUPLEIX, Louis DENAUD, Laurent BLÉRON, Rémy MARCHAL, Mark HUGHES - The effect of log heating temperature on the peeling process and veneer quality: beech, birch, and spruce case studies - European Journal of Wood and Wood Products - Vol. 71, n², p.163-171 2013 


\title{
The effect of log heating temperature on the peeling process and veneer quality: beech, birch, and spruce case studies
}

\author{
Anna Dupleix $\cdot$ Louis-Etienne Denaud • \\ Laurent Bleron · Rémy Marchal · Mark Hughes
}

\begin{abstract}
Heating green-wood prior to peeling is necessary to improve both peeling process and quality of veneer. This study investigates optimum heating temperatures by soaking of beech, birch and spruce. Experiments have studied the influence of heating temperatures from 20 to $80{ }^{\circ} \mathrm{C}$ on thickness deviations and veneer lathe checking using a pneumatic rugosimeter and image analysis of opening checks with the SMOF device (Système de Mesure de l'Ouverture des Fissures). Conclusions account for reduced heating temperatures compared to the temperatures currently in-use in the industry. Already at $50{ }^{\circ} \mathrm{C}$, positive effects of heating ensure efficient peeling process. Low temperatures produce veneers with deeper and more spaced checks than high temperatures when checks are closer and less deep, becoming even unpredictable especially in case of spruce. These results establish the SMOF as an essential non-destructive control device to control the quality of the veneer produced at research level.
\end{abstract}

\section{Einfluss der Aufheiztemperatur des Rundholzes auf den Schälprozess und die Furnierqualität am Beispiel von Buche, Birke und Fichte}

Zusammenfassung Um den Schälprozess und die Qualität von Furnier zu verbessern, muss das Rundholz vor dem Schälen aufgeheizt werden. Dieser Artikel beschäftigt sich

A. Dupleix $(\bowtie) \cdot$ L.-E. Denaud · L. Bleron · R. Marchal Arts et Metiers ParisTech LaBoMaP, Rue Porte de Paris, 71250 Cluny, France

e-mail: anna.dupleix@ensam.eu

A. Dupleix · M. Hughes

Department of Forest Products Technology,

School of Chemical Technology, Aalto University, 00076 Aalto, Finland mit der Untersuchung der optimalen Aufheiztemperatur bei der Wässerung von Buche, Birke und Fichte. Unter Verwendung eines druckluftbetätigten Rugosimeters und digitaler Bildanalyse mittels SMOF-Apparat wurde der Einfluss einer Temperatur zwischen 20 und $80{ }^{\circ} \mathrm{C}$ auf die Dickenschwankungen und Risse der Furniere untersucht. Die Ergebnisse zeigen, dass die aktuell in der Industrie verwendeten Temperaturen reduziert werden könnten. Schon bei $50{ }^{\circ} \mathrm{C}$ kann ein effizienter Schälprozess erreicht werden. Bei niedrigeren Temperaturen treten tiefere Risse in größerem Abstand auf. Im Vergleich dazu sind bei höheren Temperaturen der Abstand und die Tiefe der Risse geringer, beim Schälen von Fichte sogar kaum meßbar. Die Ergebnisse zeigen, dass der SMOF-Apparat zur zerstörungsfreien Qualitätsprüfung von Furnieren im Rahmen von Forschungsarbeiten geeignet ist.

\section{Introduction}

For almost all hardwood and softwood species, the heating of green wood prior to peeling is necessary in order to successfully produce veneer. Industrially, this is generally accomplished by soaking-immersing the whole logs in hot water basins-or by steaming them in vats. These traditional methods mainly use water as the medium to transfer heat into the bulk wood (Daoui et al. 2007). Heating is a key stage in the processing of wood prior to peeling since it influences material properties and consequently modifies cutting mechanisms. An energy approach has shown that the ratio of fracture to shearing energies increases with heating (Thibaut and Beauchene 2004). This has a positive effect on (1) the peeling process and (2) veneer quality. Firstly, a diminution in the energy dissipated in the shearing of wood lowers the pressure applied 
by the bolt on the cutting knife, thereby decreasing the effort required in peeling (Bédard and Poulain 2000) and consequently diminishing power consumption and cutting tools wear (Marchal et al. 2004). Secondly, the reduction in the fracture energy required to create a unit area of surface, reduces the formation of checks and therefore improves veneer quality (Thibaut and Beauchene 2004).

In practice, the effects of peeling temperature on cutting effort and veneer quality are species dependent. The results from various experimental factors are then interpreted to reach a compromise leading to threshold temperatures defined as the optimum heating temperatures. Determining the optimal conditions for each species necessitates dedicated experimental campaigns. On the one hand, measuring cutting forces requires peeling lathes equipped with automated sensors that are both costly and difficult to install in an industrial environment. On the other hand, veneer "quality" (encompassing thickness variation, veneer roughness and lathe checking) necessitates only basic instrumentation and can be evaluated by hand or by manual image analysis, but is time-consuming and, as yet, cannot be done online. This is the reason why current experimental results tend to be qualitative and provide only limited statistical accuracy. This lack of a rigorous analysis procedure has led to the introduction of empirical approaches by industrial operators who use temperature as a guide to obtaining satisfactory veneer quality. Consequently, soaking temperatures are not even consistent from one company to another for the same species. Soaking temperatures are often raised to increase thermal transfer and reduce soaking duration. It is all the more problematic as the consequences of overheating are known to be detrimental to veneer quality as it leads to the formation of 'wooly' surfaces and can cause block spin-outs due to a reduction in the shear strength of wood. Overheating at reduced soaking times also affects the temperature homogeneity within the bolt; the outer sapwood is overheated whilst the temperature of the heartwood is not high enough. Recent research has, however, combined the results of quantitative factors to evaluate veneer quality and veneer processing as a function of soaking temperature and could eventually lead to changes in the way industry controls its processes (Dai and Troughton 2011).

This present paper contributes to advances in the evaluation of veneer quality and veneer processing as a function of soaking temperature. The method employs a purpose designed instrument-SMOF (Systeme de Mesure d'Ouverture des Fissures)-for the quantitative measurement of lathe checking (Palubicki et al. 2010)—and the fuitometer-a pneumatic rugosimeter (see Sect. 2)-to assess veneer surface quality. This study was conducted on two hardwood species: beech (Fagus sylvatica) and birch (Betula pendula) — and one softwood species; spruce (Picea albies). These species are amongst the most commonly used in northern countries to industrially produce wood-based panels and plywood. The aim of this article is to measure the effect of $\log$ heating temperatures on the veneer quality of beech, birch and spruce.

\section{Materials and methods}

Bolts of $400 \mathrm{~mm}$ diameter were cut to $600 \mathrm{~mm}$ length to fit the dimensions of the peeling lathe. For each species, all tested bolts originate from the same log and each bolt was tested at one soaking temperature. Bolts were heated by soaking in water over a $48 \mathrm{~h}$ period at temperatures ranging from 20 to $80{ }^{\circ} \mathrm{C}$. The difference between the actual temperature of the soaking water and the target temperature is represented in Fig. 1. These differences are not significant so that in the following of the article, temperatures refer to target temperatures for more clarity. The importance of knots was evaluated by taking pictures of the veneers and measuring the ratio of knots to the veneer surface with image analysis. However, the percentage of knots was always inferior to $2 \%$ in the tested veneers. Density of bolts before and after soaking varied between 725 and $1,290 \mathrm{~kg} / \mathrm{m}^{3}$ (Fig. 2). Mean ring width is presented in Table 1.

\section{Peeling process parameters}

Bolts were peeled with the industrial peeling lathe available at Arts et Metiers ParisTech Cluny, France. Pressure

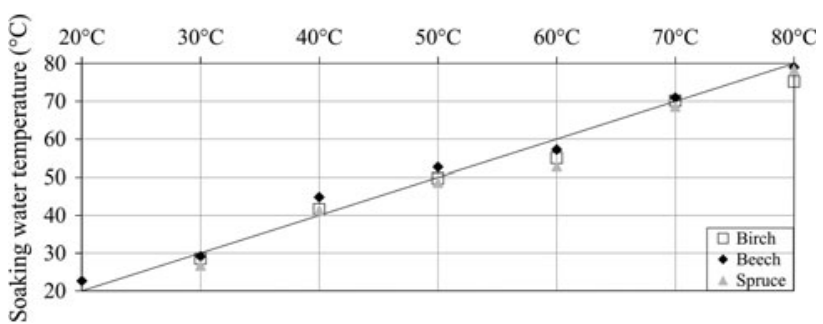

Fig. 1 Effective soaking water temperature as compared to target temperature

Abb. 1 Vorhandene Wassertemperatur im Vergleich zum Sollwert

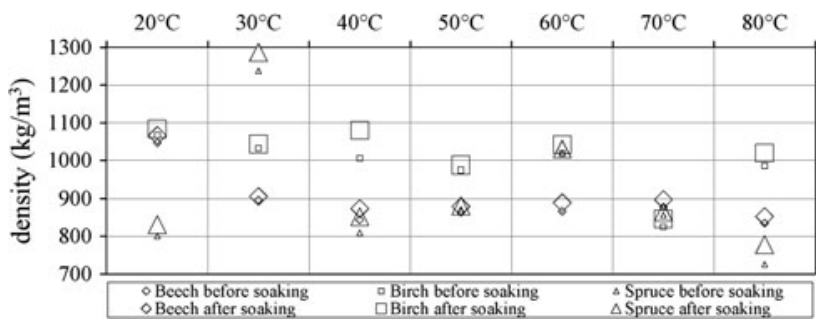

Fig. 2 Density of the bolts before and after soaking

Abb. 2 Dichte der Stammabschnitte vor und nach der Wässerung 
Table 1 Mean rating width of each tested bolt (in $\mathrm{mm}$ )

Tab. 1 Mittlere Jahrringbreite der untersuchten Stammabschnitte (in $\mathrm{mm}$ )

\begin{tabular}{llllllll}
\hline & $20{ }^{\circ} \mathrm{C}$ & $30{ }^{\circ} \mathrm{C}$ & $40{ }^{\circ} \mathrm{C}$ & $50{ }^{\circ} \mathrm{C}$ & $60{ }^{\circ} \mathrm{C}$ & $70{ }^{\circ} \mathrm{C}$ & $80{ }^{\circ} \mathrm{C}$ \\
\hline Beech & 2.7 & 2.3 & 2.1 & 2.4 & 1.9 & 2.4 & 2.7 \\
Birch & N/A & 2.5 & 4.4 & N/A & 3.3 & N/A & 2.6 \\
Spruce & 2.4 & 2.2 & 1.2 & 1.7 & 2.3 & 2.3 & 2.4 \\
\hline
\end{tabular}

bar and peeling speed influence veneer quality (Mothe 1988). The nominal veneer thickness $\mathrm{e}_{\text {nom }}$-or input thickness on the peeling machine different to the actual measured thickness of the veneer due to wood structurewas $3 \mathrm{~mm}$. In order to evaluate only the influence of heating temperatures on the peeling process and veneer surface quality, peeling speed, $\mathrm{f}$, and compression rate of the pressure bar, Bp, were kept constant (f $=1 \mathrm{~m} / \mathrm{s}$; $\mathrm{Bp}=5 \%$; vertical gap $=1 \mathrm{~mm}$ ). This low $\mathrm{Bp}$ value compared to the 15-20\% pressure bar values usually used in industry was chosen to highlight the checking phenomenon with the slightest influence of the pressure bar. In order to verify this influence, the first peeling turns on each bolt were carried out without the pressure bar.

\section{Heating temperatures}

Special attention was paid to the difficulty in measuring the surface temperature of the bolt during peeling. Two methods of measurement were used as means of crosschecking to ensure that bolts remained heated to the target temperature of the core during the whole peeling process. First, the heating water temperature was given by sensors from the soaking basins - the reference temperature. Secondly, a Fluke TiR3 infrared thermal camera whose specifications are detailed in Table 2 was used to continuously monitor in-line bolt surface temperature during peeling. In order to minimize the effects of any disturbing factors (distance object-camera, background temperature and relative humidity), the experiments were carried out in a large hall so that background temperature and relative humidity

Table 2 Infrared thermal camera specifications

Tab. 2 Technische Daten der Infrarot-Wärmebildkamera

\begin{tabular}{ll}
\hline Specifications & Analogical fluke TiR3 \\
\hline Detector & Vanadium oxide FPA microbolometer \\
Image resolution & $320 \times 240$ pixels \\
Thermal sensitivity & $\leq 0.070{ }^{\circ} \mathrm{C}$ at $30^{\circ} \mathrm{C}$ \\
Scan speed & $7.5 \mathrm{~Hz}$ \\
Spectral band & $8-14 \mu \mathrm{m}$ \\
Temperature range & -20 to $100{ }^{\circ} \mathrm{C}$ \\
\hline
\end{tabular}

did not change during experiments as recommended by Flir Systems ThermaCAM User's Manual. Moreover, the change in the distance between the camera and the bolt surface caused by the forward displacement of the knife (around $20 \mathrm{~cm}$ ) is negligible compared to the several meters separating the bolt surface from the camera (Fig. 3a). To control bolt surface temperatures, the advantage of Infrared Thermography (IRT) over other contact methods lies in its convenience in measuring the surface temperature of objects in motion. In the past, contact methods such as thermocouples to measure bolt surface temperature while rotating have proven to be difficult to implement (Bédard and Poulain 2000).

\section{Veneer surface quality}

Surface quality was assessed on wet veneers to prevent any effects of drying (Perre 2007). For each temperature, $6 \mathrm{~m}$ of veneer band were tested: 10 replicates corresponding to 10 randomly chosen lathe turns, each of $600 \mathrm{~mm}$ length (Fig. 3b).

\subsection{Thickness variation}

Thickness deviation from the nominal thickness, $\mathrm{e}_{\text {nom }}$, is a control of veneer surface unevenness. Thickness variation was measured every $70 \mathrm{~mm}$ along the veneer length with a digital micrometer (Fig. 3b). The principle relies on a weighed pipe which pins at same pressure the veneer against a marble surface to ensure $10 \mu \mathrm{m}$ thickness precision.

\subsection{Veneer air leakage}

Given the lack of standard for veneer surface quality evaluation, it was decided to assess it by measuring air leakage on veneer surface with a pneumatic rugosimeteralso referred to as a fuitometer. The fuitometer offers many advantages amongst which are rapidity — a few seconds per veneer ribbon, ease of handling, low price, the possibility to measure wet surfaces, robustness. This method has proven its ability in the assessment of paper surface quality as well as in particle board and panel manufacturing (Coelho 2005). In case of veneer, roughness, due either to intrinsic defects of the wood structure (tracheids in softwood, annual growth rings in hardwood veneers) or to defects generated by the knife action or the pressure bar during the peeling process, can be assessed by haptictactile feeling with fingers, optical or contact methods (Mothe 1985). However, none of these methods are adapted to the assessment of veneer quality in the green state. The haptic procedure-still in use in the industry by 


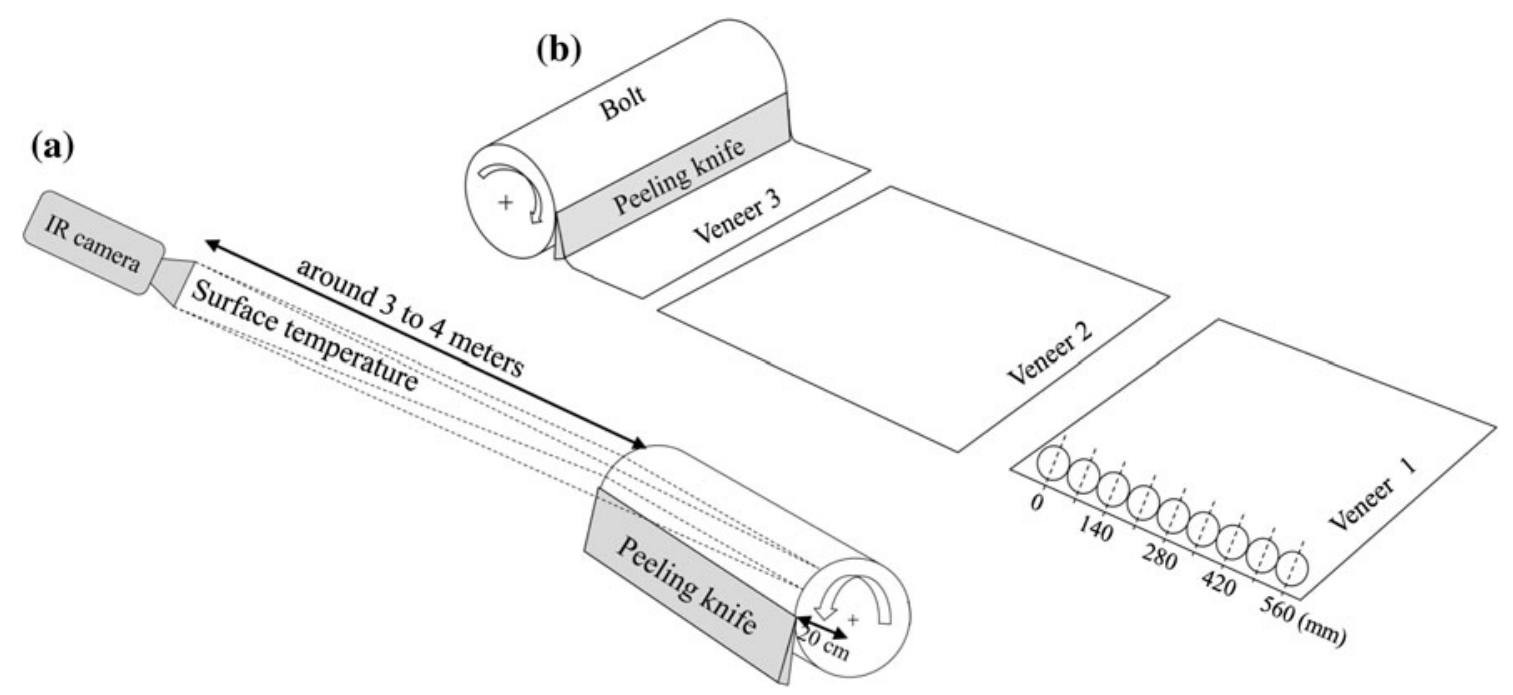

Fig. 3 Thermal imaging location (a), sampling details (b)

Abb. 3 Anordnung der Wärmebildkamera (a), Probenentnahme (b)

experienced operators at the end of veneer production lines-uses touch which gives only qualitative results impossible to correlate with quantitative measures of roughness commonly used in surface metrology. Optical rugosimeters - such as laser methods - are also not adapted to evaluate the surface quality of wet veneers: the results are dispersive due to the presence of interacting water. The precision of contact rugosimeters at the micrometer scale compared to the heterogeneity of veneers surface at millimeter scale, limits the measurements that can be conducted in an affordable time to small-size samples which weakens the representativeness of the measurements (Tanritanir et al. 2006).

The principle of the fuitometer is simple (Pouzeau and Pradal 1957). It is based on pressure loss when air flows through an annular-shaped pipe impinging on the uneven veneer surface (Fig. 4a). In the case of an uneven surface, air leaks through the pipe: the pressure at the output of the pipe decreases leading to a pressure loss indicated by the water column whose level gets higher. The difference between input and output pressure readings on a water column is a function of veneer air permeability. The fuitometer gives the Checking Index (CI) calculated from the difference of air leakage between the tight and loose sides of the veneer (El Haouzali 2009) (Eq. 1, Fig. 4a). CI measures air leakage through veneer which is influenced by lathe check formation (Palubicki et al. 2010): the more lathe checks, the more tearing of fibers, the more uneven surface, the more air leakage, and the higher water level and thus the lower column reading. Measurements were taken every $70 \mathrm{~mm}$ along the veneer length (Fig. 3b).
CI $($ in $m m$ of water $)=$ water level $_{\text {on tight side }}$

$$
\text { - water level on loose side. }
$$

Veneer quality was measured in terms of lathe checking and thickness variation continuously along the length of the 10 replicates of veneer bands with the SMOF device (Fig. 3b).

\subsection{Lathe checking}

Lathe checking is brought about by a sudden tearing of wood fibers under the cutting knife due to an increase in the energy dissipated by wood shearing (Thibaut and Beauchene 2004). The mechanisms behind the formation of lathe checking are influenced by the deformability of the wood and so, in turn, depend upon the peeling temperature. Checks form on loose side in contact with the knife while tight side is in contact with the pressure bar (Fig. 4b). Lathe checking on the loose side was detected with the SMOF device (Palubicki et al. 2010). The principle consists in bending veneer over a pulley to visualize checks exposed to a laser. A camera automatically takes pictures of the veneer thickness enabling a continuous recording of the veneer cross-section. The resulting information given is the interval between two checks CIni (Eq. 2) and checking depths CDi for each check i (Eq. 3). The advantage of the SMOF is that it provides CDi calculated as a percentage of the actual veneer thickness $e_{i}$ at the position of the check $x_{i}$ while manual methods refer to nominal veneer thickness enom (Fig. 4b). 

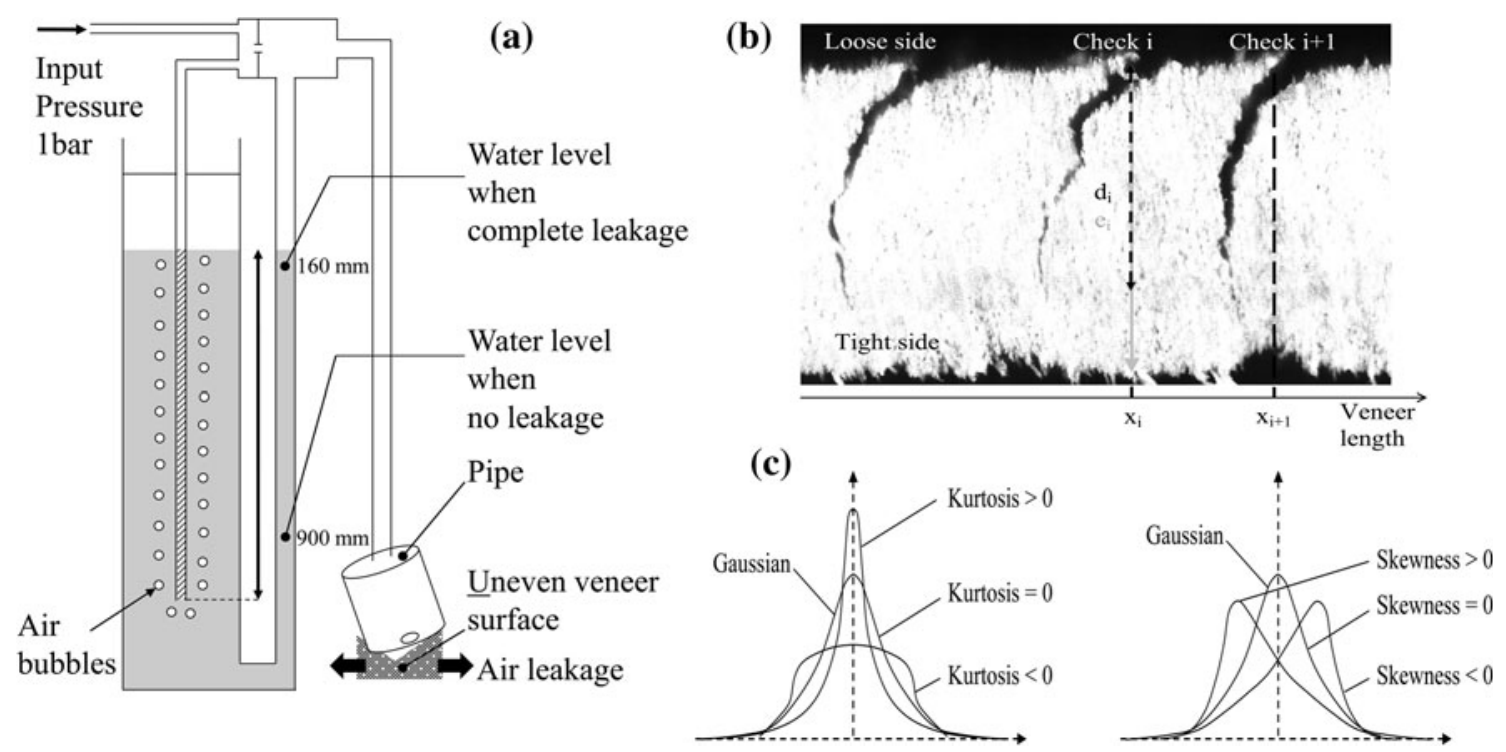

Fig. 4 Scheme of the fuitometer principle (a), SMOF output image (b), definitions of kurtosis and skewness for a distribution of data (c) Abb. 4 Funktionsprinzip des Fuitometers (a), mit SMOF erzeugtes Bild (b), Wölbung und Schiefe einer Dichteverteilung (c)

$\mathrm{CIn}_{\mathrm{i}}($ in $\mathrm{mm})=\mathrm{x}_{\mathrm{i}+1}-\mathrm{x}_{\mathrm{i}}$

$\mathrm{CD}_{\mathrm{i}}($ in $\%)=\frac{\mathrm{d}_{\mathrm{i}}}{\mathrm{e}_{\mathrm{i}}} \times 100$

For each check $\mathrm{i}$, the Checking Ratio $\mathrm{CR}_{\mathrm{i}}$ is given by Eq. (4):

$\mathrm{CR}_{\mathrm{i}}=\frac{\mathrm{CIn}_{\mathrm{i}}}{\mathrm{CD}_{\mathrm{i}}}$

The advantage of SMOF is the automated numerical imaging of the horizontal and vertical positions of lathe checks within the loose face of veneer (Palubicki et al. 2010). It therefore provides an automatic way of assessing the depth and intervals of checking in the large-scale production of veneers. However, the reliability of SMOF needs to be proven in a vast series of experimental tests.

\subsection{Thickness variation}

This information was provided by a LVDT sensor located on the SMOF device.

\section{Results and discussion}

In the present experiments, IRT detected small variations in surface temperature during peeling. This may be due to the presence of a residual temperature gradient within the bolt or to the variation of emissivity with modification of surface quality which arise during peeling process (Meola et al. 2004).

\subsection{Thickness variation}

For beech and birch the standard deviations are low (around $2-3 \%$ of veneer thickness) and are constant with the heating temperature (Fig. 5). These results indicate that the cutting process is already stable at low temperatures with no plunging knife cycles. The standard deviations, at around 4-6\%, are higher in spruce than in either beech or birch. Thickness variation decreased as the heating temperature rose, demonstrating the positive effects of heating on veneer thickness consistency (Fig. 5). However, these conclusions should be treated with a little caution due to some inconsistency in the results obtained at 30 and $70{ }^{\circ} \mathrm{C}$. These inconsistencies results might be explained by the heterogeneous structure of spruce softwood at the microscopic levels compared with the homogeneous structures of beech and birch hardwoods (Navi and Heger 2005).

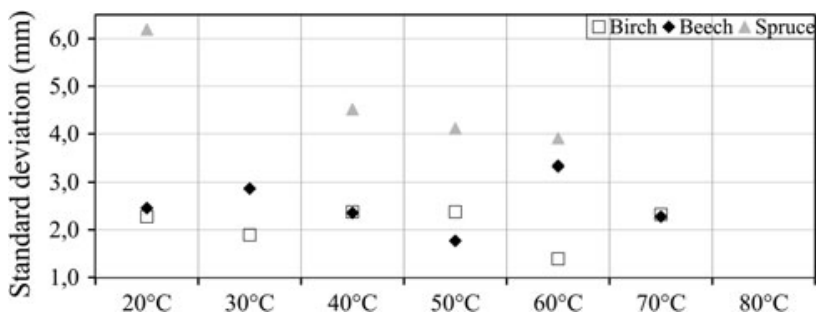

Fig. 5 Influence of heating temperature on thickness variation (COV) Abb. 5 Einfluss der Aufheiztemperatur auf die Dickenschwankung (COV) 


\subsection{Veneer air leakage}

Apart from the inconsistent results for spruce at $80{ }^{\circ} \mathrm{C}$ which may be due to experimental mistake, $\mathrm{CI}$ is found to

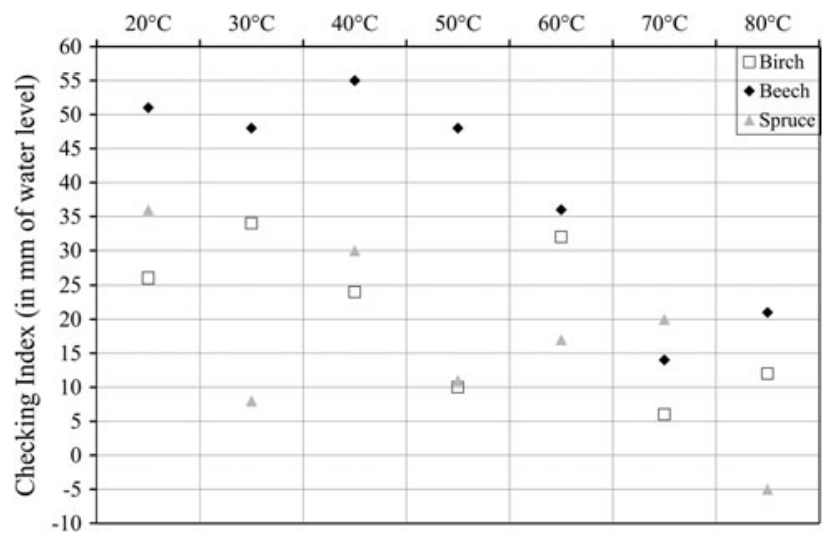

Fig. 6 Influence of heating temperature on checking index (CI) Abb. 6 Einfluss der Aufheiztemperatur auf den Rissindex (CI) be always positive denoting that air leakage on loose side is higher than on tight side (Fig. 6). This observation indicates that fuitometer may be used to qualitatively evaluate the amount of lathe checking that forms on veneer loose side (Eq. 1, Fig. $4 \mathrm{a}$ ). Up to $70^{\circ} \mathrm{C}$, CI decreases with heating temperatures indicating a reduction in lathe check depth and demonstrating the positive influence of heating on reducing veneer lathe checking. The slight subsequent increase noticeable for beech and birch from $80{ }^{\circ} \mathrm{C}$ may be due to the commencement of the formation of wooly surfaces and deeper checks (Fig. 6). The fuitometer gives a mean value of the measured surface quality: the results are not as precise results as the SMOF in terms of different $\mathrm{CD}_{\mathrm{i}}$ and $\mathrm{CIn}_{\mathrm{i}}$, however. The resulting information is less valuable and offers only a general overview of the influence of soaking temperature on lathe checking. However, the fuitometer is a reliable alternative to the SMOF for stiff species which cannot bend over the pulley.
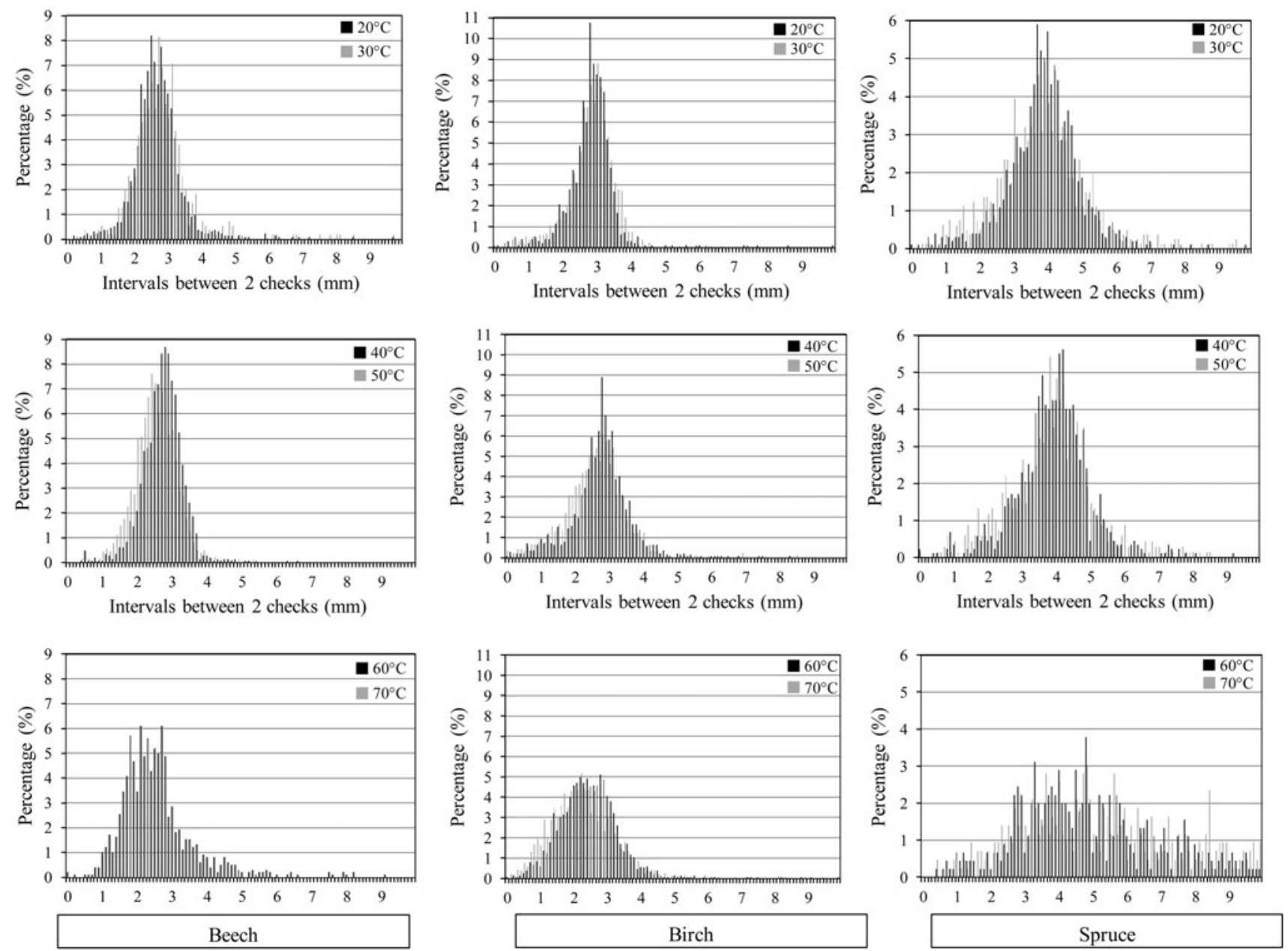

Fig. 7 Diagrams of the distribution of intervals between two checks function of heating temperatures Abb. 7 Verteilung der Rissabstände in Abhängigkeit der Aufheiztemperatur 

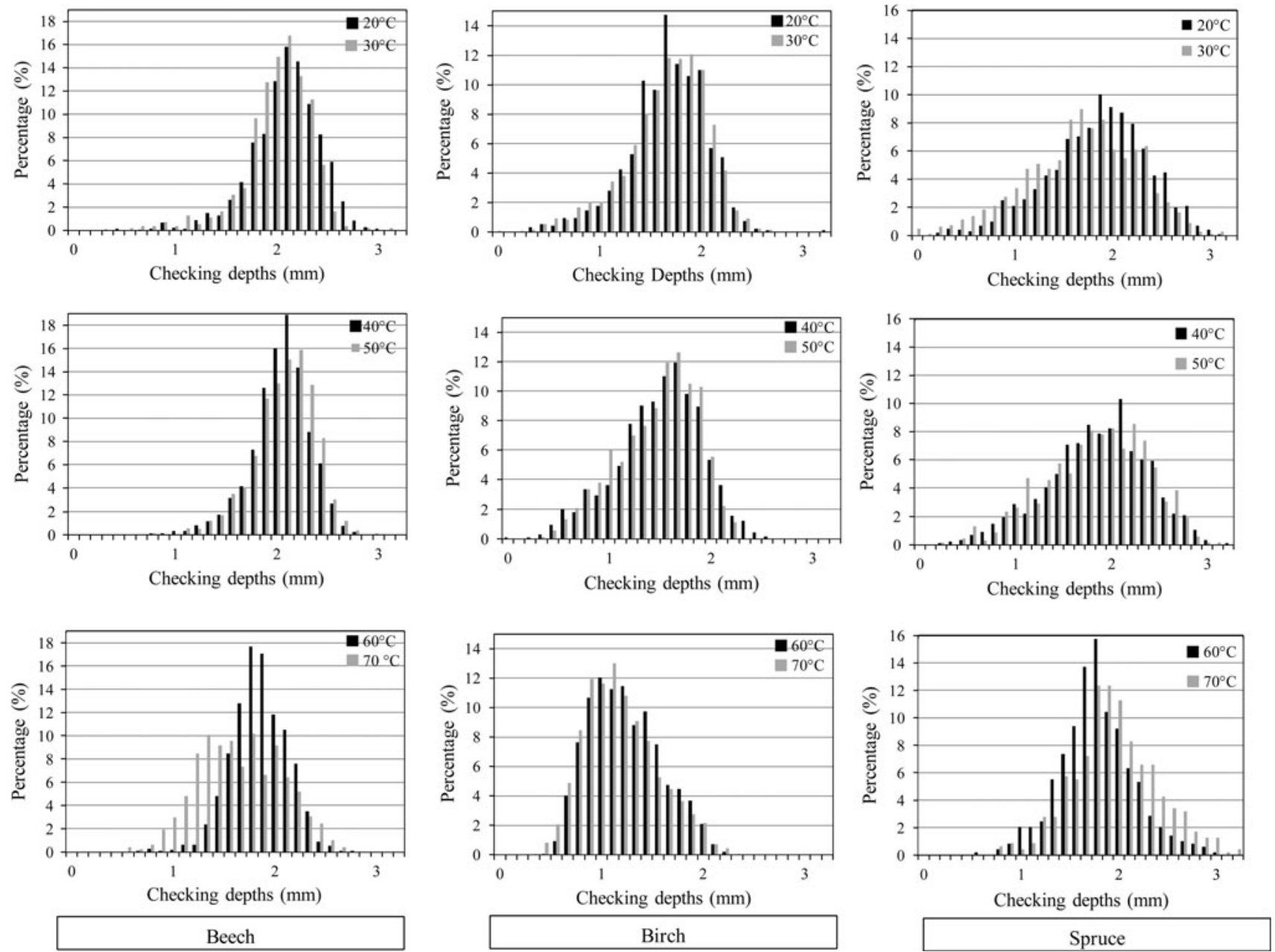

Fig. 8 Diagrams of the distribution of checking depths function of heating temperatures Abb. 8 Verteilung der Risstiefe in Abhängigkeit der Aufheiztemperatur

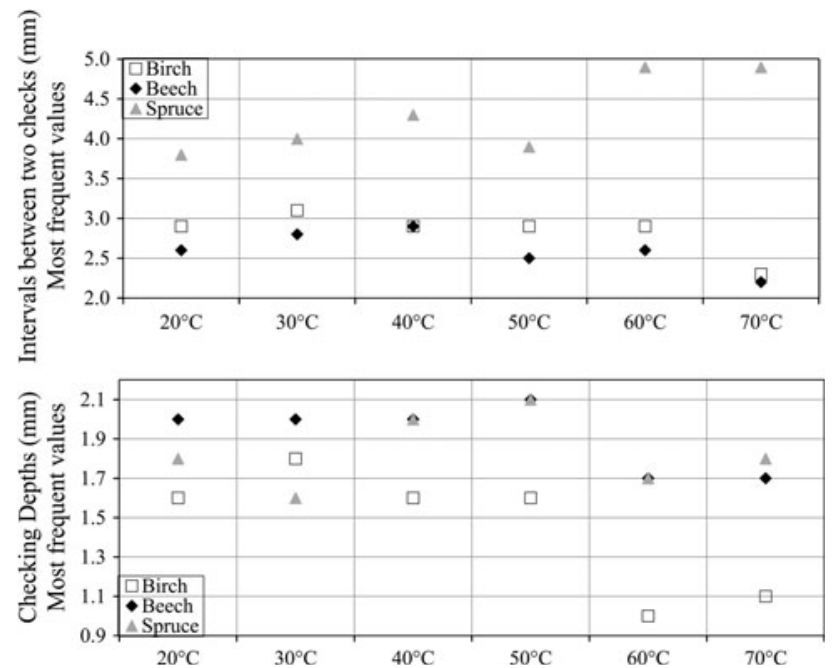

Fig. 9 Influence of heating temperatures on the most frequent values for intervals between two checks and checking depths

Abb. 9 Häufigste Werte der Rissabstände und der Risstiefe in Abhängigkeit der Aufheiztemperatur

\subsection{Lathe checking}

The SMOF provides statistical data about the intervals between two checks $\mathrm{CIn}_{\mathrm{i}}$ (Eq. 2) and check depths $\mathrm{CD}_{\mathrm{i}}$ (Eq. 3), giving precise distributions of these two values along all of the 6 meters of tested veneer. The distributions are displayed in the form of histograms (Fig. 7 for the intervals between two checks and Fig. 8 for check depths). For each heating temperature, they represent the number of lathe checks (in terms of percentages of total number of lathe checks on the measured veneer) for each range of $\mathrm{CIn}_{\mathrm{i}}$ and $\mathrm{CD}_{\mathrm{i}}$ displayed in the $X$-axis. For each heating temperature, the highest percentage represents therefore the most frequent values of $\mathrm{CIn}_{\mathrm{i}}$ and $\mathrm{CD}_{\mathrm{i}}$. The most frequent values offer the advantage over the less representative mean values to bring all information concerning checking distribution along the veneer length (Fig. 9).

All three species feature the same behaviour for check depths: check depths are roughly constant at temperatures 

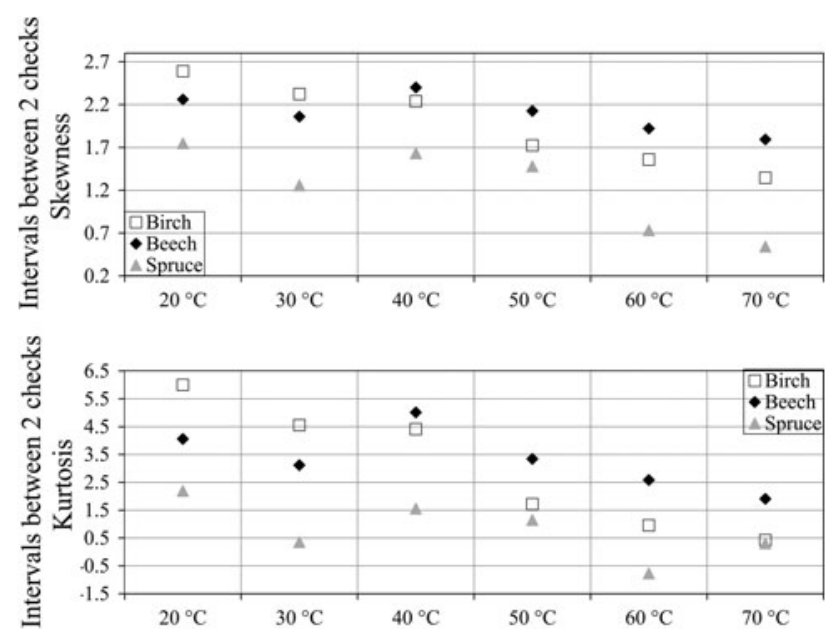

Fig. 10 Influence of heating temperatures on skewness and kurtosis for intervals between two checks

Abb. 10 Schiefe und Wölbung der Verteilung der Abstände zwischen zwei Rissen in Abhängigkeit der Aufheiztemperatur

up to $60{ }^{\circ} \mathrm{C}$, before starting to decrease from this point on. This means that high heating temperatures produce veneers with smaller lathe check depth. With respect to the interval between two checks, beech and birch behave alike and in the same manner as for check depths, namely that high heating temperatures tend to produce veneers with a greater number of more closely spaced checks. Spruce, however, does not exhibit the same behaviour at temperatures of 60 and $70{ }^{\circ} \mathrm{C}$. In these two cases, diagrams spread wide so that there is no significant surpassing value and most frequent values are not statistically relevant (Fig. 7). For this reason a statistical analysis is chosen to evaluate the coefficients of skewness and kurtosis for the diagrams (Fig. 4c). Skewness is a measure of the asymmetry of the distribution while kurtosis is a measure of its peakedness. For all species, the kurtosis and skewness of the intervals between two checks tend to decrease with heating temperatures (Fig. 10). Spruce kurtosis and skewness are lower than for beech and birch at all temperatures and kurtosis-drops below 0 and skewness becomes negative at 60 and $70 \circ \mathrm{C}$.

The conclusions that can be drawn are that the checks are deeper and more widely spaced at low temperatures than at high temperatures which produce smaller but more closely packed checks. These results should, in theory, be verified by a constant Checking Ratio (Thibaut 1988) as confirmed in Fig. 11.

This implies that the mechanisms of lathe check formation becomes unpredictable as the heating temperatures rises. This phenomenon could be interpreted as the growing impact of wood anatomy together with a reduction of the stress field-due to reaching the glass transition temperature $\mathrm{T}_{\mathrm{g}}$. The softening of wood is dictated by the glass transition temperature $T_{g}$ of cell wall lignin which occurs

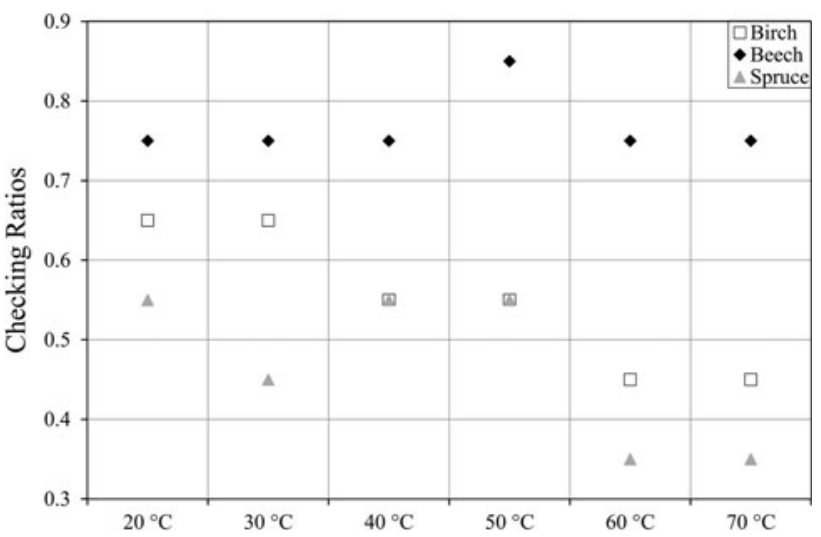

Fig. 11 Influence of heating temperatures on checking ratios Abb. 11 Einfluss der Heiztemperatur auf die Rissigkeit

in the range of $50-100{ }^{\circ} \mathrm{C}$ for green wood (Olsson and Salmen 1997). These interpretations are confirmed in the case of spruce. Spruce features a strong heterogeneity between early and late wood (Raiskila et al. 2006) and a higher lignin content (Fengel and Wegener 1984), which may explain the more significant impact of heating temperature than on either homogeneous species such as beech or birch.

\section{Conclusion}

For beech, birch and spruce, it is difficult to define optimum heating temperatures based on the results that have been obtained. However, compared to previous results (Dai and Troughton 2011), the breakthrough in this study is to rely on check distribution as a function of heating temperature. Heating of beech, birch and spruce produces veneers with closer lathe checks of smaller depth than low temperatures which produce veneers with deeper and more widely spaced checks. At high temperatures, the check formation mechanism is less periodic and becomes governed by wood anatomy and is therefore less predictableespecially in the case of heterogeneous spruce. Such results are useful in providing to industrial operators the decisionmaking values to design optimum heating temperatures with regard to lathe checking tolerance as a function of veneer end uses. In that sense, this study highlights the role played by lowered temperatures in veneer quality. Such lowered temperatures point the way towards the development of an alternative to soaking that would use infrared heating for example (Dupleix et al. 2012). Moreover, this study demonstrates the efficiency of the SMOF device to quantify veneer lathe checking (by means of the intervals between two checks and checking depths) at industrial scale (high number of tested veneer meters). These results establish the SMOF as an essential non-destructive control 
tool for plywood manufacturers to control the quality of the veneer produced. This justification of the SMOF creates a potential for industrials to develop the SMOF as in-line measurement system on the edge of the veneers-on the supposition that edge effects do not introduce inaccuracy in the results. Further studies should establish the link between lathe checking and gluing with respect to the mechanical properties of plywood. Heating temperatures would then be determined according to the check distribution required as a function of the end-uses of the veneers.

Future work could describe lathe checking with checking frequency $\mathrm{CF}$ by taking into account peeling speed, $\mathrm{s}$ (Eq. 5, Fig. 4b). The interest in using CF over checking intervals $\mathrm{CIn}_{i}$ is to draw a comparison with frequencies of acoustic signals emitted by the cutting knife during peeling (Denaud et al. 2012).

$\mathrm{CF}($ in $\mathrm{Hz})=\frac{1}{\mathrm{x}_{\mathrm{i}+1}-\mathrm{x}_{\mathrm{i}}} \times \mathrm{s}$

\section{References}

Bédard N, Poulain A (2000) Application de l'infrarouge au réchauffage de billes pour produits forestiers Donohue-essais de laboratoires (Application of infrared heating to bolts for forest products Donohue-experimental tests). Technical report, Hydro Québec

Coelho CMP (2005) Influence de l'usinage du bois sur les caractéristiques objectives et sur la perception subjective de l'aspect d'une finition (Influence of wood machining on objective characteristics and subjective perception of the aspect of finishing). $\mathrm{PhD}$ thesis, Faculdade de Engenharia da Universidade do Porto

Dai C, Troughton GE (2011) Effect of log conditioning temperature on veneer quality. Technical report, FP Innovations

Daoui A, Douzet J, Marchal R, Zerizer A et al (2007) Valorisation du bois de pin d'alep par déroulage: optimisation de l'étuvage (Valorisation of Aleppo pine for peeling: optimisation of soaking). Bois et Forêts des Tropiques 294(4):51-64

Denaud LE, Bleron L, Eyma F, Marchal R (2012) Wood peeling process monitoring: a comparison of signal processing methods to estimate veneer average lathe check frequency. Eur J Wood Prod 70:253-261

Dupleix A, Ould Ahmedou SA, Bleron L, Rossi F, Hughes M (2012) Rational production of veneer by IR-heating of green wood during peeling: modeling experiments. Holzforschung (accepted)
El Haouzali H (2009) Déroulage du peuplier: effets cultivars et stations sur la qualité des produits dérivés (Peeling of poplar: effects of cultivars and stations on the quality of derived products) $\mathrm{PhD}$ thesis, Arts et Métiers ParisTech

Fengel D, Wegener G (1984) Wood: chemistry, ultrastructure, reactions. Walter de Gruyter

Marchal R, Gaudilliere C, Collet R (2004) Technical feasibility of an embedded wood heating device on the slicer or the peeling lathe. 1st International Symposium Veneer Processing and Products Proceedings, pp 29-44

Meola C, Carlomagno GM, Giorlea L (2004) The use of infrared thermography for materials characterization. J Mater Process Technol 155:1132-1137

Mothe F (1985) Essai et comparaison de trois méthodes de classement de surface de bois massif pour leur rugosité: méthodes pneumatique et sensorielles (Test and comparison of three methods for grading the surface of solid wood for roughness: pneumatic and sensorial methods). Annales des Sciences Forestières 42(4): $435-452$

Mothe F (1988) Aptitude au déroulage du bois de Douglas. Conséquences de l'hétérogénéité du bois sur la qualité des placages. $\mathrm{PhD}$ thesis, Institut Polytechnique de Lorraine

Navi P, Heger F (2005) Comportement thermo-hydromécanique du bois: applications technologiques et dans les structures (Thermohydro-mechanical behaviour of wood: technological and structural applications). PPUR Presses Polytechniques

Olsson AM, Salmen L (1997) The effect of lignin composition on the viscoelastic properties of wood. Nord Pulp Pap Res 12(31):140 144

Palubicki B, Marchal R, Butaud JC, Denaud LE, Bleron L, Collet R, Kowaluk G (2010) A method of lathe checks measurement: SMOF device and its software. Eur J Wood Prod 68(2):151-159

Perre P (2007) Fundamentals of wood drying. A.R.BO.LOR

Pouzeau P, Pradal H (1957) Aspects nouveaux dans la technique de déroulage de l'Okoumé (New look in Okoumé peeling method). Bois et Forêts des Tropiques 54:41-50

Raiskila S, Saranpaa P, Fagerstedt K, Laakso T, Loija M, Mahlberg R, Paajanen L, Ritschkoff A (2006) Growth rate and wood properties of Norway spruce cutting clones on different sites. Silva Fenn 40(2):247-256

Tanritanir E, Hiziroglu S, As N (2006) Effect of steaming time on surface roughness of beech veneer. Build Environ 41(11):14941497

Thibaut B (1988) Le processus de coupe du bois par déroulage, PhD thesis, Institut Polytechnique de Lorraine

Thibaut B, Beauchene J (2004) Links between wood machining phenomena and wood mechanical properties: the case of $0^{\circ} / 90^{\circ}$ orthogonal cutting of green wood, 2nd International Symposium on Wood Machining, pp 149-160 